\title{
The influence of playing video games on academic performance among graduates of Karunya University
}

\author{
G. Arockiyasamy ${ }^{1, *}$ K. Surendheran ${ }^{2}$ Sujeevan Kumar Bullard ${ }^{3}$ \\ 1, 2 Karunya University, Coimbatore, India
}

Keywords:

Video games

Academic performance

University students

Addictive technologies

Received: 9 April 2016

Accepted: 25 April 2016

Published: 21 June 2016

\begin{abstract}
This study aims to determine whether the students of Karunya University are engaged in such games that impact their academic performance. A random sampling survey method is used. The students of various disciplines were randomly selected as respondents of the study. The academic performance of the students is collected from the controller of examinations of Karunya University. The finding reveals that the students' choices in video game genres are significantly correlated with their overall performance indicated by the CGPA (.924). Similarly, the average time spent in such engagement per week is significantly correlated with the academic performance which gave out the value of (0.842). The results also reveal that the students' history of gaming since they were kids is positively connected with their overall academic performance, which is revealed by the correlation value of $(0.982)$. The outcome also shows that the correlation between students' engagement with video gaming and their academic performance in the first year of their college life is relatively higher than the subsequent years. In conclusion, video game selection and time spent is significant in Karunya students' academic performance. The rest of the variables in the study were insignificant. The findings could be useful for teachers to understand student behavior better and improve their learning.
\end{abstract}

(c) 2016 The Author(s). Published by TAF Publishing.

\section{INTRODUCTION}

In the present globalized market-driven world, Human progress and development is highly influenced by the power of information and technology. The technologically driven world spins around the information explosion and technological resources. Dr.Digumarti Bhaskara Rao states "The emergence of the "Learning Society" amongst advanced technology economies with its concomitant knowledge updating and renewal for individuals creates new expectations". The developing countries have come to realize the role and need of skills with latest technology for the future generation.

Human alone is capable of learning and transferring his understanding to some other destinations. This capacity of his mind is often referred to as skill development. This ability has made the civilization to progress over the

\footnotetext{
* Corresponding author: G. Arockiyasamy

E-mail: arockiasamy@karunya.edu
} 
centuries. This communicative function is based on skill development in various countries. Whatever it may be but no one can deny today the impact of handling latest devices by younger generation. The paradigm shift in educational theory is due to growing use of advanced digital technology and ICT. As Dr. Satyaprakash noted in his article, "Several studies have been conducted regarding the use of ICT. IT helps students because more reflection and autonomy develop their critical thinking skill, increase motivation by offering more diverse and authentic learning resources and this brings the outside world to Class-room". The gaming environment has taken the most part of today's younger generation. So it is the concern of this paper.

\section{Objectives}

The main objective of this study is to find out the influence of playing video games from childhood till graduation on academic performance of Karunya University students. Gaming involves various factors inter-related to the students' learning process. These factors are bound to influence the nature of their academic involvement. So, this study will also aim to trace out the interconnectivity between those factors and students' academic performances. To find out the social elements linked with students' academic performance is also one of the objectives of this study. It also aims at finding out the influences caused by the departmental affiliation of the students.

\section{REVIEW OF LITERATURE}

Video gaming is an unavoidable environment for younger generation because it has the potential for maximum interactivity and fun. Besides, the technocrats are investing their resources and are in a race to come up with newer concepts in innovating these gaming devices. An article, Startups explore beyond reality with AR and VR written by Ayyar (2016) in a newspaper notes that "It is compatible with all existing PC games, movies and one can live-stream from online gaming communities". This clearly shows that how vital this gaming is for the future younger generations and hence this area requires a lot of researches. Playing 3D video games may boost memory-says an article in a newspaper (Times of India, December 10, 2015) which refers to a research conducted by Craig Stark and Dane Clemenson of UCI's Centre, California. The research has found that playing 3D video games such as 'Super Mario' may boost the memory power of the gamers.

A study was carried out by the Nanyang Technological University, Singapore on Children and Video Games: Addiction, Engagement, and Scholastic achievement. In this study, Skoric et al. (2009) indicated that addiction tendencies in video gaming are consistently negatively related to scholastic performance (Lee, 2015). While, no such relations are found for either time spent playing games or video gaming engagement. He concludes that there is no relationship at all between video game playing tendency and academic performance. Another study, A Study of Time Management: The Correlation between Video Game Usage and Academic Performance Markers, from New York conducted by Anand (2007) states that video games may have a detrimental effect on an individual Grade-Point Average (GPA) and possibly on Scholastic Aptitude Test (SAT) scores. This conclusion is different due to SAT scores that are repeated. One more study, how computer games help children 
learn conducted by Shaffer (2006) points out that the new "smart games" will give students the knowledge and skills they need to adapt to the changing world. Based on this theory, the students playing video games might have more adaptability towards their academics.

On the contrary, there are a few studies that explore the negative side of video gaming and digital technologies. One such study is referred in an article, Dizzy? It could be cybersickness by Murphy (2015) that refers to a research at Coventry University's Centre for mobility and transport in England. It states that, "It is a natural response to an unnatural environment". It also says that digital balance is lost due to motion created in gaming or similar devices which causes dizziness. It also says that there is nausea due to watching fast-moving digital images becoming common. The above researches urged us to study the habit of video gaming that has any effect on the academic performance of the gamers.

\section{METHODOLOGY}

It is commonly known that playing video games extensively will have detrimental effects on academic performances of the students. On the other hand, some other studies warrant that the academic performance could be improved due to playing video games. These studies also show that the student's cognitive skills are also being enhanced as an additional outcome of gaming. So, there are some unclear assumptions which led us to investigate the relationship between their gaming habits and their academic performance. To carry out the study, we included all students from various departments of Karunya University as the population. This study used survey method as the tool to collect data from the respondents. A convenient sampling method was used to identify the respondents needed for the study. We limited the total number of respondents' amount to eighty. The study used Chi-Square and Correlation analysis to find out the significance.

\section{Operational Definition}

Video game playing is measured through the duration of playing, what type of gaming device they are using, the familiarity with the type of games, how long they have been playing games since childhood as well as the playing habits during the college life taken into account on yearly basis. Students' academic performance is measured by their cumulative results. The factors influencing the habit of video game playing are kept as students learning process and these factors are also measured. 


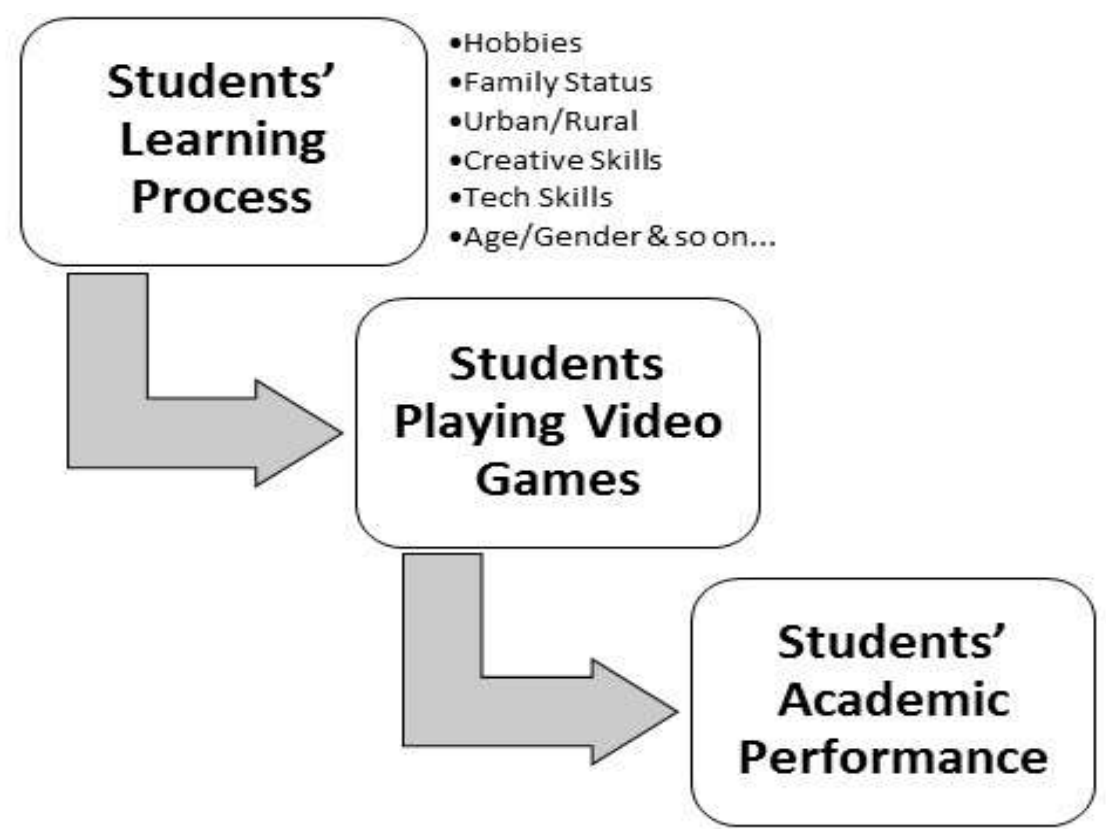

FIGURE 1. Conceptual framework

FINDINGS AND DISCUSSIONS

TABLE 1. Frequency and percentage of personal characteristics of the respondents

\begin{tabular}{|c|c|c|c|}
\hline \multirow{4}{*}{ Age Group } & $10-15 Y r s$ & $\begin{array}{l}\text { Frequency } \\
1\end{array}$ & $\begin{array}{l}\text { Percent } \\
1.25\end{array}$ \\
\hline & $16-20 Y r s$ & 60 & 75 \\
\hline & $21-25 \mathrm{Yrs}$ & 18 & 22.5 \\
\hline & 26 and above & 1 & 1.25 \\
\hline \multirow{2}{*}{ Gender } & Male & 61 & 76.25 \\
\hline & Female & 19 & 23.75 \\
\hline \multirow{2}{*}{$\begin{array}{l}\text { You are from which part of } \\
\text { the country? }\end{array}$} & Rural Area & 14 & 17.5 \\
\hline & $\begin{array}{l}\text { Urban Area } \\
\text { None }\end{array}$ & $\begin{array}{l}65 \\
1\end{array}$ & $\begin{array}{l}\mathbf{8 1 . 2 5} \\
1.25\end{array}$ \\
\hline \multirow{3}{*}{$\begin{array}{l}\text { What's your family income } \\
\text { per month? (approx) }\end{array}$} & $\begin{array}{l}\text { Rs } 15,000 \text { or less } \\
\text { Rs } 15,001 \text { - } \\
\text { Rs } 30,000\end{array}$ & $\begin{array}{l}6 \\
16\end{array}$ & $\begin{array}{l}7.5 \\
20\end{array}$ \\
\hline & $\begin{array}{l}\text { Rs } 30,001- \\
\text { Rs50,000 }\end{array}$ & 22 & 27.5 \\
\hline & $\begin{array}{l}\text { Above Rs } 50,000 \\
\text { None }\end{array}$ & $\begin{array}{l}35 \\
1\end{array}$ & $\begin{array}{l}43.75 \\
1.25\end{array}$ \\
\hline
\end{tabular}


The above table reveals that majority sixty respondents are Male and it means 76 percent of the respondents are male. Similarly, 65 respondents that is eightyone percent of the respondents come from Urban setup. Sixty respondents are belonging to the age group between sixteen to twenty years of age that amounts to seventy-five percentage of the total respondents Around 35 respondents only play game because they have a family income of above fifty thousand rupees as monthly income. Majority of the video game players are males who come from Urban area having a monthly income of above Rs. 50,000. They belong to the age group of 16 to 20 years old.

TABLE 2. Frequency and Percentage of Video Game Playing Habit

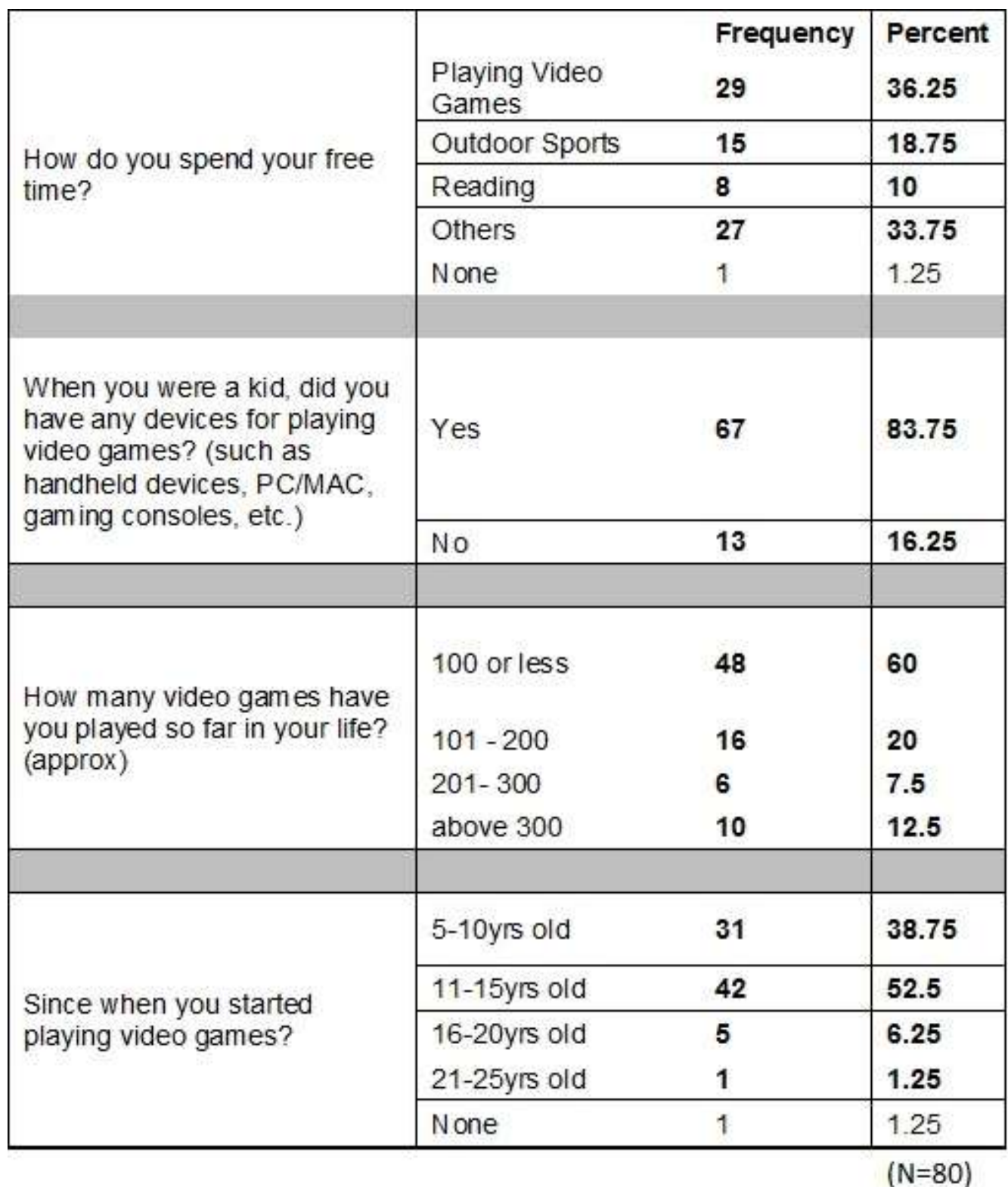

Table 2 shows that more than fifty percent of the respondents started to play video games from the age of eleven and around sixty percent of them have 
played around one hundred games. Eighty-three of them played such games from the time they were kids using various types of gaming devices and consoles. Thirty-six percent of the total respondents used to spend their free time on playing video games. It also shows that after the age of fifteen the video game playing habit has decreased.

TABLE 3. Frequency and percentage of playing video games

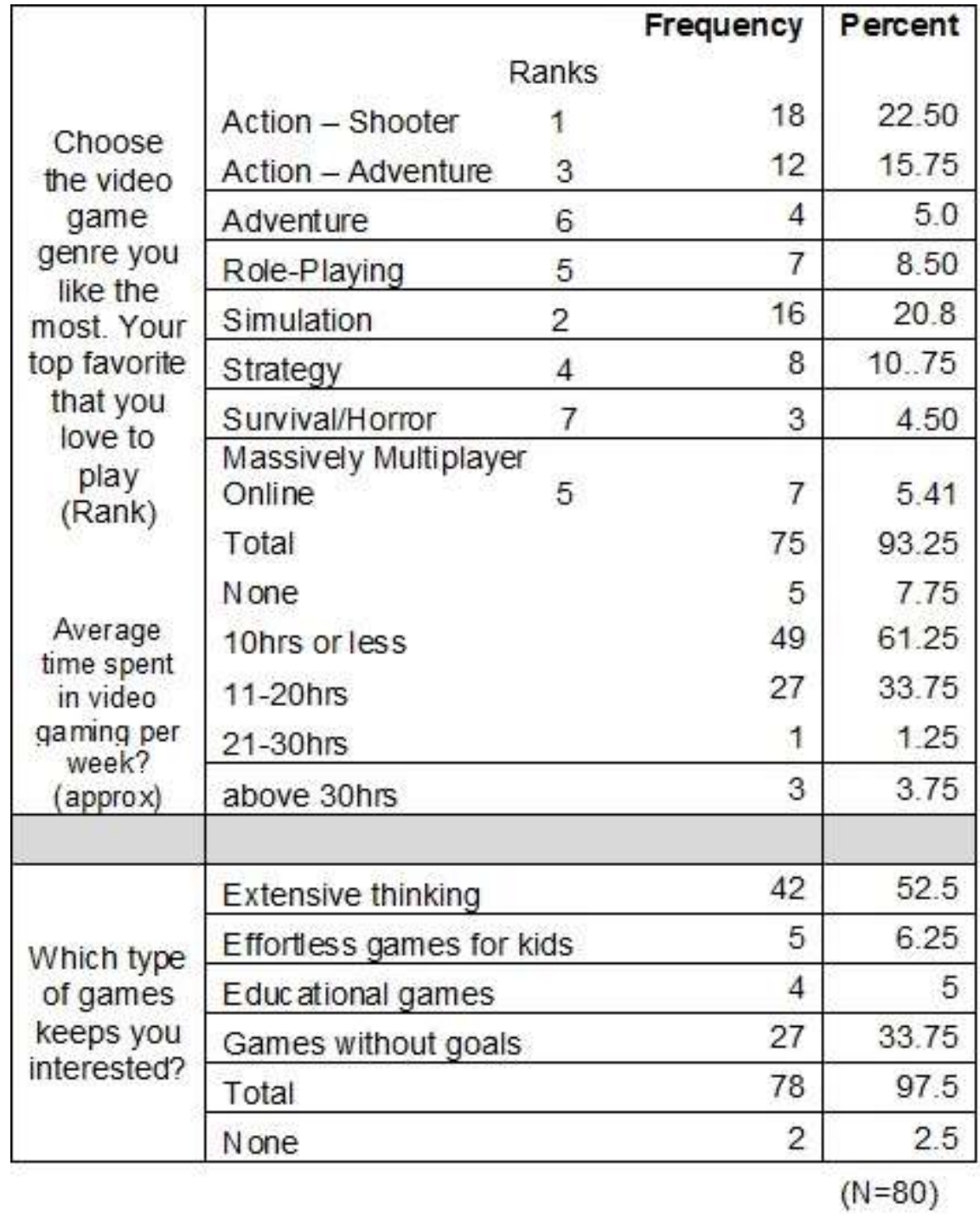

Table above shows that the respondents have played variety of games and they have ranked them in order of preferences. The action shooter games are highly ranked and preferred as the first type of game. Simulation games are ranked as the second best game. Action adventure games are ranked as the third highly preferred games by number of respondents. Survival or Horror games as well as adventure are least ranked by the respondents.

Sixty-one percent that is 49 respondents play zero to ten hours and another thirty-three percent that is around twenty-seven respondents play video games for eleven to twenty hours per week. Very few respondents have indicated that they play video games for more than twenty hours per week. Majority of the respondents (42) that is fifty-two percent say that extensive thinking involved 
games they are interested in. Another (27) respondents that amount to thirtythree percent said games without goals are very interesting.

TABLE 4. Frequency and Percentage of Video game playing habits

\begin{tabular}{|c|c|c|c|}
\hline \multirow{7}{*}{$\begin{array}{c}\text { How do you prefer to play } \\
\text { video games? }\end{array}$} & & Frequency & Percent \\
\hline & Alone & 31 & 38.75 \\
\hline & With Fam ily & 4 & 5 \\
\hline & With Friends & 38 & 47.5 \\
\hline & $\begin{array}{l}\text { With } \\
\text { Strangers }\end{array}$ & 5 & 6.25 \\
\hline & Total & 78 & 97.5 \\
\hline & None & 2 & 2.5 \\
\hline \multirow{5}{*}{$\begin{array}{c}\text { In which way you are } \\
\text { introduced to newer/recent } \\
\text { video games? }\end{array}$} & $\begin{array}{l}\text { Self } \\
\text { Family }\end{array}$ & $\begin{array}{r}17 \\
8\end{array}$ & $\begin{array}{r}21.25 \\
10 \\
\end{array}$ \\
\hline & Classmates & 48 & 60 \\
\hline & $\begin{array}{l}\text { Gaming } \\
\text { Cafes }\end{array}$ & 5 & 6.25 \\
\hline & Total & 78 & 97.5 \\
\hline & None & 2 & 2.5 \\
\hline \multirow{4}{*}{$\begin{array}{l}\text { Which device do you use } \\
\text { often to play video games? }\end{array}$} & $\begin{array}{l}\text { Smartphones } \\
\text { Gaming } \\
\text { Consoles }\end{array}$ & $\begin{array}{r}22 \\
4\end{array}$ & $\begin{array}{r}27.5 \\
5\end{array}$ \\
\hline & $\begin{array}{l}\text { PC/MAC } \\
\text { Other } \\
\text { Handhelds }\end{array}$ & $\begin{array}{r}50 \\
1\end{array}$ & $\begin{array}{l}62.5 \\
1.25\end{array}$ \\
\hline & Total & 77 & 96.25 \\
\hline & None & 3 & 3.75 \\
\hline
\end{tabular}

The above table indicates that forty-seven percent of the respondents that is 38 in number play video games with friends and another thirty-eight percent that is 31 of them play the video games alone. Very few respondents play the video games with any other person. Sixty percent of the respondents said they were introduced to video games by their classmates and twenty-one percent of them were self-introduced to video games. Sixty-two percent of the respondents said that PC/MAC was the commonly used device for this purpose and twenty-seven percent said Smartphones were used often for playing video games. 
TABLE 5. Frequency and percentage of video gaming and attitude of respondents

\begin{tabular}{|c|c|c|c|}
\hline & & Frequency & Percent \\
\hline \multirow{6}{*}{$\begin{array}{c}\text { Since when you started playing } \\
\text { video games? }\end{array}$} & $\begin{array}{l}5-10 y r s \\
\text { old }\end{array}$ & 31 & 38.75 \\
\hline & $\begin{array}{l}11-15 y r s \\
\text { old }\end{array}$ & 42 & 52.5 \\
\hline & $\begin{array}{l}16-20 y r s \\
\text { old }\end{array}$ & 5 & 6.25 \\
\hline & $\begin{array}{l}21-25 y r s \\
\text { old }\end{array}$ & 1 & 1.25 \\
\hline & Total & 79 & 98.75 \\
\hline & None & 1 & 1.25 \\
\hline \multirow{3}{*}{$\begin{array}{l}\text { "Playing video games helped me in my } \\
\text { acadmic performance."- State your } \\
\text { opinion. }\end{array}$} & Aaree & 26 & 32.5 \\
\hline & Disagree & 21 & 26.25 \\
\hline & $\begin{array}{l}\text { I don't } \\
\text { kvnow }\end{array}$ & 33 & 41.25 \\
\hline \multirow{4}{*}{$\begin{array}{l}\text { redo you munch snacks while } \\
\text { playing video games? }\end{array}$} & $\begin{array}{l}\text { Yes. } \\
\text { Always }\end{array}$ & 7 & B. 75 \\
\hline & $\begin{array}{l}\text { Yes, } \\
\text { often }\end{array}$ & 17 & 21.25 \\
\hline & $\begin{array}{l}\text { Yes, } \\
\text { Rarely }\end{array}$ & 31 & 38.75 \\
\hline & No & 25 & 31.25 \\
\hline
\end{tabular}

The above table shows that ninety percent of the respondents said that they started to play the video games from the age five to fifteen years. It reveals that only ten percent feel that they started to play after sixteen years of age. Forty one percent of the respondents were not sure of academic influence due to video game playing. Out of the remaining fifty-nine percent of the respondents thirty-two percent have agreed that playing video games affects academic performance while twenty-one percent denied such influence.

TABLE 6. Frequency and percentage of video game playing habit

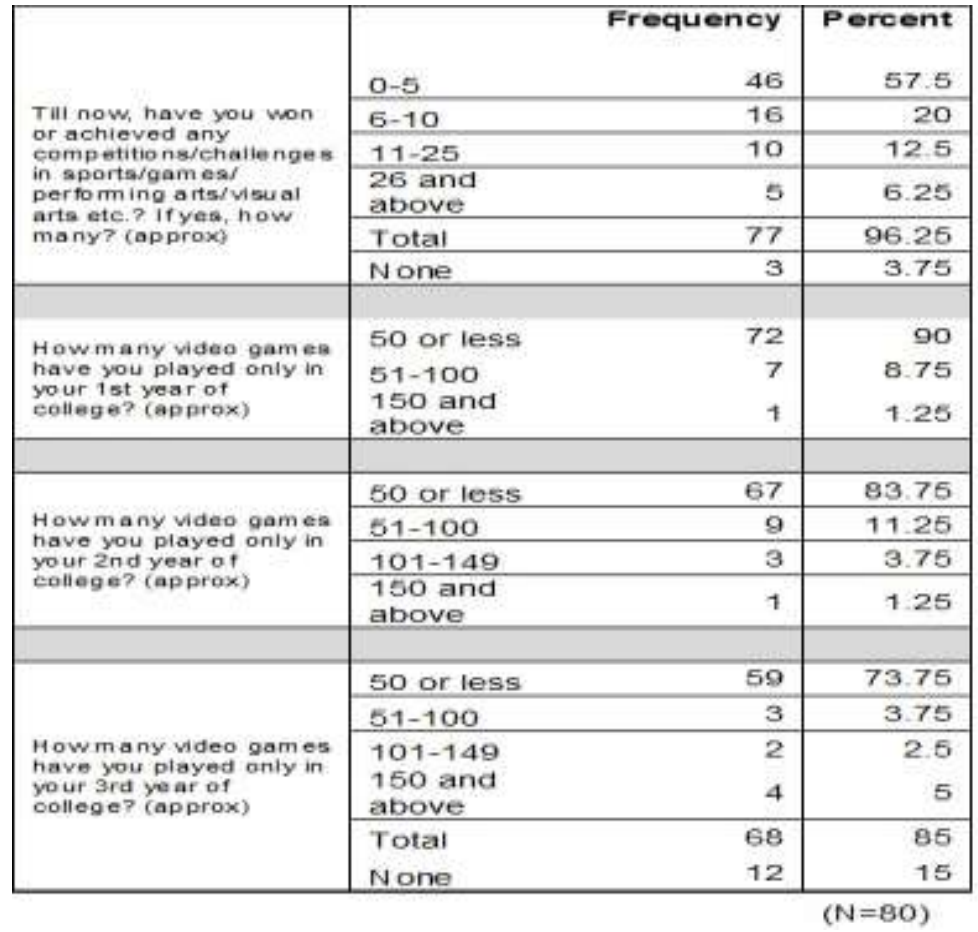


The above table indicates that around seventy-seven percentage of respondents said that they have won five to ten awards in various competitions. While comparing total three years of college life, during the first year ninety percent of respondents used to play but in the second year it went down to eighty-three percent and in the third year it went even further down to Seventythree percent.

TABLE 7. Correlation between personal factors and academic performance

\begin{tabular}{|c|c|c|c|c|c|c|}
\hline \multicolumn{7}{|c|}{ Correlations } \\
\hline & & Age Group & Gender & $\begin{array}{l}\text { You are from } \\
\text { which part of } \\
\text { the country? }\end{array}$ & $\begin{array}{l}\text { What's your } \\
\text { family income } \\
\text { per month? } \\
\text { (approx) }\end{array}$ & Orerall CGPA \\
\hline \multirow[t]{3}{*}{ Age Group } & Pearson Correlation & 1 & .030 & .083 & -.072 & $-255^{\circ}$ \\
\hline & Sig. (2-tailed) & & 793 & 468 & .526 & .022 \\
\hline & $\mathrm{N}$ & 80 & 80 & 79 & 79 & 80 \\
\hline \multirow[t]{3}{*}{ Gender } & Pearson Correlation & .030 & 1 & .028 & .075 & 139 \\
\hline & Sig. (2-talled) & 793 & & .803 & .512 & 220 \\
\hline & $\mathrm{N}$ & 80 & 80 & 79 & 79 & 80 \\
\hline \multirow{3}{*}{$\begin{array}{l}\text { You are from which part of } \\
\text { the country? }\end{array}$} & Pearson Correlation & .083 & .028 & 1 & .214 & .064 \\
\hline & Sig. (2-tailed) & 468 & .803 & & .060 & 577 \\
\hline & $\mathrm{N}$ & 79 & 79 & 79 & 78 & 79 \\
\hline \multirow{3}{*}{$\begin{array}{l}\text { What's your family income } \\
\text { per month? (approx) }\end{array}$} & Pearson Correlation & -.072 & .075 & 214 & 1 & -070 \\
\hline & Sig. (2-tailed) & .526 & .512 & .060 & & 541 \\
\hline & $\mathrm{N}$ & 79 & 79 & 78 & 79 & 79 \\
\hline \multirow[t]{3}{*}{ Overall CGPA } & Pearson Correlation & $-.255^{\circ}$ & .138 & .064 & -.070 & 1 \\
\hline & Sig. (2-tailed) & .022 & .220 & 577 & .541 & \\
\hline & N & 80 & 80 & 79 & 79 & 80 \\
\hline
\end{tabular}

${ }^{*}$ Correlation is significant at the 0.05 level (2-ailed)

The above table indicates that age group and overall academic performance are significantly correlated at the 0.05 level (2-tailed). It is significant because the table shows the value $r=.2172$ but the above table provides CGPA as .255 that is higher than the critical value of the Chi-Square table. At certain age the respondents are highly involved in video game playing and it has helped in academic output. Gender or place and income have no influence at all.

Table 8. Correlation of playing video games and academic performance

\begin{tabular}{|c|c|c|c|c|c|c|}
\hline \multicolumn{7}{|c|}{ Carrefations } \\
\hline & & 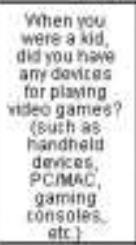 & 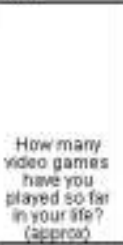 & 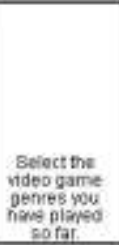 & 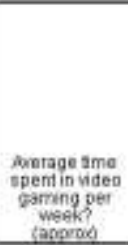 & ONeral COPA \\
\hline \multirow{3}{*}{ 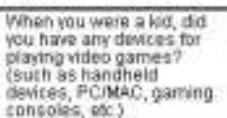 } & Pearson Comsiation & 1 & -078 & -165 & 135 & 000 \\
\hline & Eig. 2 tailedo & & 490 & 142 & 231 & 882 \\
\hline & N & $\infty 0$ & An & 00 & 60 & en \\
\hline \multirow{3}{*}{ 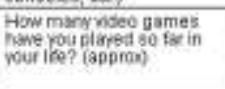 } & Pearsen Colretation & 078 & 1 & $410^{\prime \prime}$ & $480^{\prime}$ & .600 \\
\hline & Big. (2-1ailed) & 490 & & 000 & .000 & set \\
\hline & $\mathrm{N}$ & $\infty$ & 60 & 00 & 80 & 80 \\
\hline \multirow{3}{*}{$\begin{array}{l}\text { Selest this vdea game } \\
\text { perres yau have plasyed } \\
\text { so far. }\end{array}$} & Pearzon Correlation: & -165 & $410^{\circ}$ & $\frac{1}{1}$ & $428^{-1}$ & ont \\
\hline & 519 (2-taled) & 144 & 000 & & 000 & 924 \\
\hline & $\mathrm{N}$ & 80 & Bo & $B B$ & 80 & 80 \\
\hline \multirow{3}{*}{ 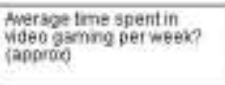 } & Pearsen Coirelation & 135 & $450^{4}$ & $428^{\prime \prime}$ & 1 & 023 \\
\hline & 5ig. (2-4ailets) & $23 t$ & 000 & 000 & & 842 \\
\hline & $\mathrm{N}$ & 80 & 80 & 00 & 80 & 80 \\
\hline \multirow[t]{3}{*}{ Oneral COPA } & Pasracen Comeiation & .003 & -005 & 011 & 023 & 1 \\
\hline & Sig (2.talledf) & $982:$ & 985 & 924 & 842 & \\
\hline & $\mathrm{N}$ & 80 & $B 0$ & $B D$ & 80 & 80 \\
\hline
\end{tabular}


The Critical value of Chi-square table $r=.2172$

The amount of time spent on video game playing and what genre of games they played and the number of games they played are significantly correlated because the table shows $r=.480, .410$ and 428 . Since they are above the critical value $r=.217$ they all are significant. It also shows that the amount of video games played by the respondents in life so far is significantly correlated to the video game genre and time spent per week at 0.05 level (2-tailed),

TABLE 9. Correlation between gaming habits and performance in studies

\begin{tabular}{|c|c|c|c|c|c|c|}
\hline \multicolumn{7}{|c|}{ Correlations } \\
\hline & & $\begin{array}{l}\text { How do you } \\
\text { preser to plar, } \\
\text { videa games? }\end{array}$ & $\begin{array}{l}\text { Which device } \\
\text { do you use } \\
\text { often to play } \\
\text { video games? }\end{array}$ & $\begin{array}{l}\text { "Plasing video } \\
\text { games } \\
\text { helped me in } \\
\text { my acadmic } \\
\text { performance." } \\
\text { - State your } \\
\text { coinion. }\end{array}$ & $\begin{array}{l}\text { Till now, have } \\
\text { you won or } \\
\text { achieved ary } \\
\text { competitionsy } \\
\text { chalenges in } \\
\text { sportsigames } \\
\text { jperforming } \\
\text { artshrisual } \\
\text { arts etc. If } \\
\text { yes, how } \\
\text { many? } \\
\text { fanptos }\end{array}$ & Overall CQPh \\
\hline \multirow{3}{*}{$\begin{array}{l}\text { How do you preder to play } \\
\text { video games? }\end{array}$} & Fearson Correlaton & 1 & $351^{\prime \prime}$ & -.001 & .093 & -015 \\
\hline & Sig. (2-tailed) & & .002 & 991 & 427 & 895 \\
\hline & $N$ & 78 & 76 & 78 & 75 & $7 \mathrm{a}$ \\
\hline \multirow{3}{*}{$\begin{array}{l}\text { Which derice do you use } \\
\text { often to play video } \\
\text { games? }\end{array}$} & Pearson Correiaton & $351^{\prime \prime}$ & 1 & .089 & -.051 & -003 \\
\hline & Sy. (2-tailect) & 002 & & 440 & .664 & 982 \\
\hline & N & 76 & 77 & 77 & 74 & 77 \\
\hline \multirow{3}{*}{$\begin{array}{l}\text { Playing video games } \\
\text { helped me in my acadmic } \\
\text { performance." - state yout } \\
\text { opinion. }\end{array}$} & Pearson Correlation & .001 & -069 & 1 & 011 & .000 \\
\hline & Sig. (2-tailed) & 991 & 440 & & 923 & 993 \\
\hline & $\mathrm{N}$ & 78 & $\pi$ & 80 & 77 & 80 \\
\hline \multirow{3}{*}{$\begin{array}{l}\text { Till now, hare you won or } \\
\text { achieved any } \\
\text { compestionsichallenges } \\
\text { in } \\
\text { sportsigamestoerforming } \\
\text { aitswisual arts etc? If } \\
\text { yes, how marm? (appros) }\end{array}$} & Pearson Correlation & .093 & -051 & 011 & 1 & -067 \\
\hline & 5ig. (2-talie() & 427 & 664 & 923 & & 565 \\
\hline & $N$ & 75 & 74 & 77 & 77 & 77 \\
\hline \multirow[t]{3}{*}{ Cmerail CQPA } & Peasson Correiation & -015 & -.003 & .000 & -.067 & 1 \\
\hline & Big. (2+tailed) & 895 & 982 & .993 & .565 & \\
\hline & $\mathrm{N}$ & 78 & 77 & 80 & 77 & 80 \\
\hline
\end{tabular}

The critical value provided by the table $r=.2172$. In the above table value of $r$ is more so the use of device by the respondents and preference of playing video games are significantly correlated at 0.05 level (2-tailed). All other factors are not correlated significantly.

TABLE 10. Correlation between three years of video gaming and Academic performance

\begin{tabular}{|c|c|c|c|c|c|}
\hline \multicolumn{6}{|c|}{ Correlations } \\
\hline & & $\begin{array}{l}\text { How many } \\
\text { video games } \\
\text { have you } \\
\text { played only in } \\
\text { your } 1 \text { st year } \\
\text { of college? } \\
\text { (approx) }\end{array}$ & $\begin{array}{l}\text { How many } \\
\text { video games } \\
\text { have you } \\
\text { played only in } \\
\text { your } 2 \text { nd year } \\
\text { of college? } \\
\text { (approx) }\end{array}$ & $\begin{array}{l}\text { How many } \\
\text { video games } \\
\text { have you } \\
\text { played only in } \\
\text { your } 3 \text { rd year } \\
\text { of college? } \\
\text { (approx) }\end{array}$ & Overall CGPA \\
\hline \multirow{3}{*}{$\begin{array}{l}\text { How many video games } \\
\text { have you played only in } \\
\text { your 1st year of college? } \\
\text { (approx) }\end{array}$} & Pearson Correlation & 1 & $.652^{\prime \prime}$ & $.658^{\prime \prime}$ & .053 \\
\hline & Sig. (2-tailed) & & .000 & .000 & .642 \\
\hline & $N$ & 80 & 80 & 68 & 80 \\
\hline \multirow{3}{*}{$\begin{array}{l}\text { How many video games } \\
\text { have you played only in } \\
\text { your } 2 \text { nd year of college? } \\
\text { (approx) }\end{array}$} & Pearson Correlation & $.652^{\prime \prime}$ & 1 & $.770^{\prime \prime}$ & -.033 \\
\hline & Sig. (2-tailed) & .000 & & .000 & .774 \\
\hline & $N$ & 80 & 80 & 68 & 80 \\
\hline \multirow{3}{*}{$\begin{array}{l}\text { How many video games } \\
\text { have you played only in } \\
\text { your 3rd year of college? } \\
\text { (approx) }\end{array}$} & Pearson Correlation & $.658^{\prime \prime}$ & $.770^{\circ}$ & 1 & -.032 \\
\hline & Sig. (2-tailed) & .000 & .000 & & .793 \\
\hline & $N$ & 68 & 68 & 68 & 68 \\
\hline \multirow[t]{3}{*}{ Overall CGPA } & Pearson Correlation & .053 & -.033 & -.032 & 1 \\
\hline & Sig. (2-tailed) & .642 & .774 & .793 & \\
\hline & $N$ & 80 & 80 & 68 & 80 \\
\hline
\end{tabular}

*. Correlation is significant at the 0.01 level (2-tailed). 
The critical value in the statistical table is $r=.2172$ at $\mathrm{df}=80$. The above table indicates that the video game playing habit in the first year is significantly correlated to the second year of playing and the second year playing is significantly correlated to the third year of playing video games. Since the above table value .652 for second year and .658 for third year are above .217 they are significantly correlated. Similarly, second year is correlated with third year at .770. The years of playing video games is correlated at .05 level. But they are not correlated with the academic performance.

Test Statistics

\begin{tabular}{|c|c|c|c|c|c|}
\hline & $\begin{array}{l}\text { When you } \\
\text { were a kid, } \\
\text { did you have } \\
\text { any devices } \\
\text { for playing } \\
\text { video games? } \\
\text { (such as } \\
\text { handheld } \\
\text { devices, } \\
\text { PCimAC, } \\
\text { gaming } \\
\text { consoles, } \\
\text { etc.) }\end{array}$ & $\begin{array}{l}\text { How many } \\
\text { video games } \\
\text { have you } \\
\text { played so far } \\
\text { in your life? } \\
\text { (approx) }\end{array}$ & $\begin{array}{l}\text { Select the } \\
\text { video game } \\
\text { genres you } \\
\text { have played } \\
\text { so far. }\end{array}$ & $\begin{array}{l}\text { Average time } \\
\text { spent in video } \\
\text { gaming per } \\
\text { week? } \\
\text { (approx) }\end{array}$ & Overall CGPA \\
\hline Chi-Square & $36.450^{=}$ & $54.800^{\mathrm{b}}$ & $13.600^{\circ}$ & $77.000^{\circ}$ & $7.500^{d}$ \\
\hline & 1 & 3 & 7 & 3 & 69 \\
\hline Asymp. Sig. & .000 & .000 & .059 & .000 & 1.000 \\
\hline
\end{tabular}

The critical value from statistical table Chi Square $r=3.84$ for $1 \mathrm{df}$ at $(0.05)$ level so the above table value is 36.4 for device like PC/Mac used when they were kids and it is significant at $1 \mathrm{df}$ and (0.05) level. Similarly, critical table value for $3 \mathrm{df}$ at (0.05) level is $r=7.81$. So, the above table value for how many video games (100 games) played $r=54.8$ is far above significant level. Average time spent category in the above table shows $r=77.0$ at $3 \mathrm{df}(0.05)$ level that is above the critical table value $r=7.81$ and therefore it is highly significant.

\section{Test Statistics}

\begin{tabular}{|c|c|c|c|c|c|}
\hline & $\begin{array}{l}\text { How do you } \\
\text { prefer to play } \\
\text { video games? }\end{array}$ & $\begin{array}{l}\text { Which device } \\
\text { do you use } \\
\text { often to play } \\
\text { video games? }\end{array}$ & $\begin{array}{l}\text { "Playing video } \\
\text { games } \\
\text { helped me in } \\
\text { my acadmic } \\
\text { performance." } \\
\text { - State your } \\
\text { opinion. }\end{array}$ & $\begin{array}{l}\text { Till now, have } \\
\text { you won or } \\
\text { achieved any } \\
\text { competitionsi } \\
\text { challenges in } \\
\text { sportsigames } \\
\text { iperforming } \\
\text { artsivisual } \\
\text { arts etc.? If } \\
\text { yes, how } \\
\text { many? } \\
\text { (approx) }\end{array}$ & Overall CGPA \\
\hline Chi-Square & $47.436^{2}$ & $78.896^{\circ}$ & $2.725^{\circ}$ & $52.714^{b}$ & $7.500^{d}$ \\
\hline & 3 & 3 & 2 & 3 & 69 \\
\hline Asymp. Sig. & .000 & .000 & .256 & .000 & 1.000 \\
\hline
\end{tabular}

The critical statistic table value for $3 \mathrm{df}(0.05)$ level is 7.81 therefore the above table $r=47.4$ for preference of video games and $r=78.8$ for device often used and $r=52.7$ for achievement in competition at $3 \mathrm{df}(0.05)$ level are above the 
critical value and therefore significant. But the games helping academic performance is below the critical level and therefore it is not significant.

Test Statistics

\begin{tabular}{|l|c|c|c|r|}
\hline & $\begin{array}{c}\text { How many } \\
\text { video games } \\
\text { have you } \\
\text { played only in } \\
\text { your 1 styear } \\
\text { of college? } \\
\text { (approx) }\end{array}$ & $\begin{array}{c}\text { How many } \\
\text { video games } \\
\text { have you } \\
\text { played only in } \\
\text { your 2nd year } \\
\text { of college? } \\
\text { (approx) }\end{array}$ & $\begin{array}{c}\text { How many } \\
\text { video games } \\
\text { have you } \\
\text { played only in } \\
\text { your 3rd year } \\
\text { of college? } \\
\text { (approx) }\end{array}$ & Overall CGPA \\
\hline $\begin{array}{l}\text { Chi-Square } \\
\text { df }\end{array}$ & $116.275^{2}$ & $149.000^{\circ}$ & $138.471^{\circ}$ & $7.500^{d}$ \\
Asymp. Sig. & 2 & 3 & 3 & 69 \\
\hline
\end{tabular}

The critical value for $2 \mathrm{df}(0.5)$ is 5.99. The above table records video games played during first year and its Chi-Square value is 116.2. So, it is above the critical value and hence it is significant. Similarly, the second year table also records Chi-Square value as 149.0 which is again above the critical value for $3 \mathrm{df}$ which is 7.82. Therefore, it is also significant. The above table records third year video game playing and its Chi-Square value is 138.4 which is above the critical table value and that is 7.82 . Therefore, it is correlated with the second year video game playing and similarly second year correlated with third year playing. But, the academic performance does not show any significance.

\section{DISCUSSIONS}

The most striking finding is that many of the variables are not correlated with the academic performance. There is no clear evidence for proving that the video game playing habits affect the academic results. The interpretation of $r$ is based on the significant level. So, if the $r$ value is between 0.00 and 0.20 , it denotes indifferent or negligible relationship. Some of the factors that we studied in the research are falling within this value and therefore they are not significant. But, the Chi-Square values of video game playing variables (devices, duration of playing, types of games, playing habits during college life) fall within 0.40 to 0.70 which indicates that there is a substantial or marked relationship between them. The objective of the study is to find out the correlation between video game playing habits and academic performance. In this regard, the value that we found between ages (5-16yrs) is correlated significantly with the academic performance (0.255). The interpretation is that there is a slight or low correlation between them.

\section{CONCLUSION}

The general perception is that the students spend much of their times in various activities other than academic-oriented programs. Most people think that it is because of other activities such as watching movies, getting social online, playing games etc. that prevent them from academic concentration. The teaching community feels the same. The authors of this research are also a part of the teaching community and wanted to find out whether this one particular fun activity of the students which is playing video games has any positive influence on their academic performance. In this research review, there were number of similar researches carried out across the world and some 
researchers boldly ascertained with their findings that there is no positive relationship between playing video games and their studies. Is this result valid for our Karunya students as well? That was the question which triggered this study and now we have found that there is only very low positive correlation between the gaming habits and studies. It is also clear that the significance is due to the influence of their age growth from 5years to 16years as a stage for maturity. That is also the same period the students' mind starting to develop towards academic concepts and may be that is why it shows slight significance. The rest of the factors did not reflect any relationship at all.

\section{LIMITATIONS AND RECOMMEDNATIONS}

In this study, it is found that there is only very low positive correlation between the gaming habits and studies. These findings are different from existing research across the world. This research may demand further intensive study in this field.

\section{REFERENCES}

Ang, Soon, Linn Van Dyne, and Christine Koh. 2005. Personality correlates of the four factor model of cultural intelligence. Group and Organization Management 31, no. 1, 100-123. DOI: doi.org/10.1177/1059601105275267

Ang, Soon, Linn Van Dyne, and Thomas Rockstuhl. 2011. Cultural intelligence. In Cambridge handbook on intelligence: 582-602, eds. Robert J. Sternberg, and Scott Barry K. New York, NY: Cambridge Press. DOI: $10.1017 /$ cbo9780511977244.030

Crowne, Kerri A. 2008. What leads to cultural intelligence? Business Horizon 51, no. 5: 391-399. D0I: 10.1016/j.bushor.2008.03.010

De Lange, Daniëlle, Filip Agneessens, and Hans Waege. 2004. Asking social network questions: A quality assessment of different measures. Metodološki zvezki 1, no. 2: 351-378.

Earley, P. Christopher, and Soon Ang. 2003. Cultural intelligence: An analysis of individual interactions across cultures. Palo Alto, CA: Stanford University Press.

Fernandes, J.A.P.S.E., and dan Andadari, R.K. 2012. Persepsi mahasiswa terhadap pemberlakuan masyarakat ekonomi ASEAN. FEB UKSW program studi S1 Manajemen, Salatiga, ID.

Friedman, Thomas L. 2005. The world is flat: a brief history of the twenty-first century. New York, NY: Farrar, Straus and Giroux.

Hair, Joseph F., and Black William C. 2000. Cluster analysis. In Reading and understanding more multivariate statistics, eds. Laurence G. Grimm, and Paul R. Yarnold, Washington DC, US: American Psychological Association.

Harrison, J. Kline, and Brower, Holly H. 2011. The impact of cultural intelligence and psychological hardiness on homesickness among study abroad students. The Interdisciplinary Journal of Study Abroad 21: 41-62.

Kanten, Pelin. 2014. The effect of cultural intelligence on career competencies and customer-oriented service behaviors. Istanbul University Journal of the School of Business 43, no. 1: 100-119.

Kitsantas, Anastasia, and Meyers, Judith. 2001. Studying abroad: Does it enhance college student cross-cultural awareness? Paper presented at the combined Annual Meeting of the San Diego State University and the U.S. Department of Education Centers for International Business Education and Research, US.

Lee, Y.H., Ko, C.H. and Chou, C., 2015. Re-visiting Internet addiction among Taiwanese students: A cross-sectional comparison of students' expectations, online gaming, and online social interaction. Journal of abnormal child psychology, 43(3), pp.589-599.

Leung, Kwok, Soon Ang and Mei Ling T. 2014. Intercultral competence. Annual Review of Organizational Psychology and Organizational Behavior 1: 489-519. DOI: 10.1146/annurev-orgpsych-031413-091229

Livermore, David. 2009. Leading with cultural intelligence. New York, NY: AMACOM.

Ng, Kok-Yee, Linn Van Dyne, and Soon Ang. 2012. Cultural intelligence: A review, reflections, and recommendations for future research. In Conducting multinational research: Applying organizational psychology in the workplace, 
eds. Ann Marie R, Frederick T.L. Leong, and Frederick L. Oswald: 29-58. Washington, DC, US: American Psychological Association. DOI: 10.1037/13743-002

Ng, Kok-Yee, and P. Christopher Earley. 2006. Culture+ intelligence old constructs, new frontiers. Group \& Organization Management 31, no. 1: 4-19. DOI: 10.1177/1059601105275251

Pangestu, Mari E. 2009. Competitiveness toward ASEAN economic community. Journal of Indonesian Economy and Business 24, no. 1: 22-32.

Rockstuhl, Thomas, Stefan Seiler, Soon Ang, Linn Van D., and Hubert Annen. 2011. Beyond general intelligence (IQ) and emotional intelligence (EQ): The role of cultural intelligence (CQ) on cross-border leadership effectiveness in a globalized world. Journal of Social Issues 67, no. 4: 825-840. DOI: 10.1111/j.1540-4560.2011.01730.x

Rose, Raduan C., and Naresh Kumar S. 2008. A review on individual differences and cultural intelligence. The Journal of International Social Research 1, no. 4: 504-522.

Shieh, Chich-Jen. 2013. Effects of culture shock and cross-cultural adaptation on learning satisfaction of mainland China students studying in Taiwan. Revista Internacional de Sociología 72, no. 2: 57-67.

Shoss, Mindy K., L. A. Witt, and Dusya Vera. 2012. When does adaptive performance lead to higher task performance?. Journal of Organizational Behavior 33, no. 7: 910-924. DOI: 10.1002/job.780

Soldatova, Galina, and Marina Geer .2013. "Glocal” identity, cultural intelligence, and language fluency. Procedia-Social and Behavioral Sciences 86: 469-474. D0I: 10.1016/j.sbspro.2013.08.599

Takeuchi, Riki, Paul E. Tesluk, Seokhwa Yun, and David P. Lepak. 2005. An integrative view of international experience. Academy of Management Journal 48, no. 1: 85-100. D0I: 10.5465/AMJ.2005.15993143

UNDP. (2013). Human development report. UNDP. URL: http://goo.gl/XDqAs4 (accessed June 16, 2016). D0I: 10.18356/a1b0c169-en

- This article does not have any appendix. - 